\title{
Finansal Oranlar Aracılığıyla Stok Yönetimi ve Karlılık İlişkisinin İncelenmesi: İmalat Sektöründe Bir Uygulama
}

\section{Investigation of the Relationship between Stock Management and Profitability by Using Financial Ratios: An Application in Manufacturing Sector}

Yakup Ülker, ${ }^{a}$ Öznur Arslan ${ }^{\text {b,* }}$

${ }^{a}$ Dr. Öğretim Üyesi, Sivas Cumhuriyet Üniversitesi, İktisadi İdari Bilimler Fakültesi, Bankacılık Finans Bölümü, Sivas/Türkiye. ORCID: 0000-0002-3070-0521

b Dr. Öğretim Üyesi, Sivas Cumhuriyet Üniversitesi, Cumhuriyet Sosyal Bilimler MYO, Büro Hizmetleri ve Sekreterlik Bölümü, Sivas/Türkiye. ORCID: 0000-0001-5973-9107

\begin{tabular}{|c|c|}
\hline MAKALE BİLGİSİ & ÖZ \\
\hline Makale Geçmişi: & İşletmelerin fiziksel unsuru olan ve karlılığını doğrudan etkileyen stokların iyi bir şekilde \\
\hline Başvuru tarihi: 01 Ocak 2020 & yönetilmesi hayati önem arz etmektedir. Çalışma, işletmelerin finansal başarısına katkıda \\
\hline Düzeltme tarihi: 08 Mart 2020 & bulunan stoklarla karlılık arasındaki ilişkiyi açıklamayı hedeflemiştir. Bu amaç \\
\hline Kabul tarihi: 23 Mart 2020 & $\begin{array}{l}\text { doğrultusunda 2013-2018 dönemindeki BISST imalat sektöründe yer alan işletmelerin } \\
\text { finansal oranları kullanılmıştır. Araştırma, stok yönetimiyle karlılıkla ilgili finansal oranlar }\end{array}$ \\
\hline Anahtar Kelimeler: & arasındaki ilişkiyi, regresyon ve korelasyon analizi kullanarak açıklamaktadır. Araştırma \\
\hline Stok Yönetimi & öz kaynak karlılık oranı arasında pozitif yönde anlamlı bir iliski söz konusu iken; brüt \\
\hline Finansal Oranlar & karlılık ve esas faaliyet karlılık oranlarını negatif yönde etkilediği tespit edilmiştir. Stok net \\
\hline Muhasebe & çalışma sermayesi oranı ile esas faaliyet karlılık oranı ve öz kaynak karlılık oranı arasında \\
\hline Karll11k & $\begin{array}{l}\text { anlamlı pozitif yönlü bir ilişkinin olduğu ve brüt çalışma sermayesi karlılığıyla arasında } \\
\text { negatif yönlü anlamlı bir ilişki olduğu saptanmıştır. Ayrıca stok dönen varlık oranı ile aktif } \\
\text { karlılık oranı, brüt çalışma sermayesi karlılı̆̆ ve öz kaynak karlılığı arasında negatif yönlü } \\
\text { anlamlı bir ilişkinin varlığı söz konusuyken stok büyüme hızı oranı ile tüm karlılık oranları } \\
\text { arasında anlamlı pozitif yönlü ilişkinin olduğu bulgusuna ulaşılmıştır. }\end{array}$ \\
\hline
\end{tabular}

\section{A R T ICLE INFO}

\section{Articlehistory:}

Received 01 January 2020

Received in revised form 08 March 2020

Accepted 23 March 2020

\section{Keywords:}

Inventory Management,

Financial Ratios,

Accounting,

Profitability

\section{A B S T R A C T}

Managing the inventory, which is a physical component of companies and directly influences the profits, is of vital importance. This study aims to explain the relationship between profitability and inventory contributing the financial success of companies. In parallel with this objective, the financial ratios of companies in Istanbul Stock Exchange's manufacturing sector between 2013 and 2018 were used. The study employs regression and correlation analysis in explaining the relationship between financial ratios related with inventory management and profitability. As a result of the analyses, it was determined that the inventory turnover has a positive and significant relationship with rate of return on assets, gross working capital, and rate of return on equity, whereas it negatively affects the rate of return on gross operating capital and rate of real operating profits. The ratio of inventory/net operating capital was found to have a significant positive relationship with real operating profitability and rate of return on equity and a significant negative relationship with return on gross operating capital. Moreover, the ratio of inventory/current assets was found to have a significant negative relationship with rate of return on assets, rate of return on gross operating capital, and rate of return on equity and the growth rate of inventory was found to have a positive relationship with all the profitability rates.

\section{Giriş}

Rekabet şartlarına dayanabilmek ve hayatlarını devam ettirebilmek isteyen işletmeler, müşterilerini memnun edebilmek ve maliyetlerini minimum seviyelere çekebilmek için harekete geçeceklerdir. $\mathrm{Bu}$ hedeflere ulaşmanın yollarından birisi de stok yönetimini etkinleştirmektir. İyi bir stok yönetimiyle doğru zamanda doğru yerde ve 
miktarda stok bulundurmakla mümkün olabilmektedir. Etkin bir stok yönetimiyle maliyetleri aşağı seviyelere çeken ve en iyi hizmeti en kısa zamanda müşterisine sunan işletmeler, rekabet avantajı sağlayacaklardır.

İşletmelerin fiziksel unsuru olan ve karlılı̆̆ını doğrudan etkileyen stokların iyi bir şekilde yönetilmesi hayati önem arz etmektedir. İşletmelerin stoklarını iyi bir şekilde yönetmesi hem stok maliyetlerini aşağı seviyelere çekecektir hem de işletme faaliyet akışlarının hızlanmasını sağlayarak müşteri memnuniyetini artıracaktır. Dolayısıyla stok politikası iyi olan işletmeler sürdürülebilir kar elde edebilecekler ve ülke ekonomisine katkıda bulunabileceklerdir.

$\mathrm{Bu}$ çerçevede hazırlanan araştırma, işletmelerin finansal başarısızlık veya finansal performansını etkileyen stok yönetiminin işletmenin karlılığı üzerindeki etkisini finansal oranlar yardımıyla tespit etmeye çalışmaktadır.

\section{Stok Yönetiminin Kavramsal Olarak İncelenmesi}

Küreselleşmenin etkisiyle rekabetin artması işletmelerin en önemli mali unsurlarından birisi olan stokların yönetimini daha da önemli bir hale getirmiştir. İşletmeler için hayati önem arz eden stok yönetiminin kavramsal çerçevesi aşağıda başlıklar halinde verilmiştir.

\subsection{Stok Kavramı}

Stok, İngilizce dilinde ki "stock" ya da "inventory" sözcüğünün karşılığg biçiminde dilimize çevrilmektedir. Farklı kaynaklarda stok kavramı yerine envanter kavramı kullanılabilmektedir (Seyidoğlu, 1992:794). “Aslında envanter, muhasebede genellikle y1l sonlarında yapılan fiziksel sayım yolu ile stok tespiti anlamına gelir. Envanter aynı zamanda işletmenin sahip olduğu ürünlerin ve servetin gerekli özellikleri ile birlikte gösterildiği ayrıntılı bir listenin hazırlanmasını ifade etmektedir. Stok, somut olup, hareketsiz duran her çeşit malzemeyi ifade eder. Envanter ise; daha geniş anlamlıdır. Stok kavramını kapsar, ancak stokun parasal değeri olarak anlaşılmaktadır" (Güneş, 2012: 52).

İşletmeler kuruluş amaçları doğrultusunda üretimi kesintisiz devam ettirmek ve müşteri isteklerini karşılayabilmek için bir takım madde ve malzemeyi ellerinde hazır bulundurmak zorundadırlar. İşletmelerin elinde hazır halde bulundurdukları bu madde ve malzemelere genel olarak "stok" denmektedir. Stok gelecekte talep edilen ve sistemdeki yetersizlikleri gideren tüm malzemelerdir (Gürçay, 2012: 17).

Stok; Türkiye Muhasebe Standartları (TMS) Stoklar Standardında, "işin normal akışı içinde satılmak için elde tutulan, satılmak üzere üretilmekte olan; ya da üretim sürecinde ya da hizmet sunumunda kullanılacak ilk madde ve malzemeler biçiminde bulunan varlıklardır" şeklinde tanımlanmıștır (Sevilengül, 2005: 291). Tekdüzen Muhasebe Sisteminde başlica stok kalemleri; İlk madde ve malzemeler, yarı mamuller, mamuller, ticari mallar ve diğer stoklar olarak sınıflandırılmıştır.

"Daha geniş bir tanımlamayla stok, üretimden daha önce tedarikçilerin elinde var olan ve sipariş sürecinde çeşitli birimlerde yer ve zaman faydası sağlanan varlıklar yanında, üretimden önceki hazır değerleri, ürerim sürecindeki ara stokları ve üretim sonrasında da depolanan veya müşterilere akışı sağlanan tüm varlıkları kapsamaktadır" (Küçük, 2011: $15)$.

\section{2. İşletmelerin Stok Bulundurma Sebepleri}

İşletmeler, gerek faaliyet gösterdikleri sektöre göre gerekse işletme politikaları açısından ellerinde stok bulundurma gereğini hissedebilirler. İşletmelerin stok bulundurma sebepleri şöyledir:

Zaman Faktörü: Birçok işletme üretime kesintisiz bir şekilde devam edebilmek için hammadde, yedek parça gibi stokları ellerinde bulundurmak ister. Dahası mevsimlik dalgalanmalardan dolayı piyasada dengeyi sağlayabilmek için de stoklara ihtiyaç duyar. İşletmelerin etkin bir stok yönetimi için üretimin planlanarak kolay ve gerçeğe uygun bir şekilde yapılması gerekmektedir.

Belirsizlik Faktörü: Talebin tahmin edilememesi, işçi grevleri, üretimin değişkenliği, yüklemelerdeki zaman kayıpları, olağanüstü hava şartları, beklenmedik talep artışı gibi işletmelerin karşılaşabileceği bir takım belirsizlikler talep edilen ürün miktarıyla tedarik edilen ürün miktarı arasındaki farkı artırarak, üretimin durması, üretimde kullanılan araç ve gereçlerin atıl kalması, potansiyel satış imkânlarını elden kaçırması gibi riskleri de beraberinde getirmektedir. Dolayısıyla bu olumsuzluklarla karşılaşmak istemeyen işletmeler stok bulundurma zorunda kalabilirler.

Ekonomi Faktörü: Stoklar işletmelerin ekonomik miktarlı ürünleri satın alarak üretimin devam etmesini sağlamaktadır. Büyük miktarlarda satın alınan madde ve malzemeler miktar indirimini de beraberinde getirebilmekte, bu durum ise işletmelere maliyetleri minimize etme avantajını yakalama şansı vermektedir. Ayrıca büyük çapta verilen siparişler ile yıl boyunca verilecek sipariş sayısını azaltmış olacak ve sipariş maliyetlerinden tasarruf edilecektir. Bu sebeplerle firmalar ihtiyaçları olandan fazla ürünü bir kerede tedarik ederek, stok bulundurmaya yönelebilirler (Tersine, 1994:7).

\subsection{Stok Maliyetleri}

Stoklar işletme varlıklarının büyük bir kısmını teşkil ederler, bu bakımdan stok maliyetlerinin hesaplanması işletme karlılığını arttırma da ve işletme zararlarını minimuma indirme de çok önemli faktör olarak dikkat çekmektedir. Bu bağlamda stok maliyetleri şöyledir:

Sermaye Maliyeti (Stok Kaleminin Kendi Maliyeti): "Stok maliyetleri içinde hesaplanması en kolay olan maliyet kalemidir. Satın alınan stok kalemi için ödenen bedeldir İlke olarak, bir stokun maliyetini onunla ilgili yapılan tüm masraf ve ödemeler oluşturur" (Kara, 2014: 24).

Sipariş Maliyetleri: Sipariş verildiği zaman ortaya çıkan maliyetlerdir. Üretim gerçekleşeceği zaman her işletme giderin doğması bakımından sipariş veya hazırlık sürecini başlatır. Stok miktarını artırmak için gerçekleşen bu işlemlerden doğan maliyetler, siparișin ișletme içinden veya dışından verilmesi bakımından farklılık göstermektedir.

Elde Bulundurma Maliyetleri: "Bulundurulan stok miktarına bağlı olarak değişen, stok miktarı arttıkça artan, azaldıkça azalan bir maliyet türüdür. $\mathrm{Bu}$ maliyetler şu şekilde örneklendirilebilir: Finansman maliyeti, stoklama, yükleme, boşaltma giderleri, depo, ambar gibi stokların muhafaza edildiği yerlerin kira, amortisman, bakım, 
onarım, 1sıtma, soğutma, aydınlatma vb. giderleri, stok hizmet giderleri (Depo bekçilerine ödenen ücretler), sigorta giderleri, stok tutma riski (malların bozulması, fiyatların düşmesi, tüketici taleplerinin değişmesi), çalınma ve doğal afetler nedeniyle uğranılan kayıplar" (Kirac1, 2009: 164).

Stok Bulundurmama Maliyetleri: "Belli bir dönemde stokları aşacak miktarda talep olması halinde, bu fazla talebin karşılanamaması sonucunda oluşan maliyet olarak tanımlanabilir. Diğer bir tanımlamayla istenilen varlığın stoklanamaması veya yeterince stoklanamaması sonucunda oluşan maliyetlerdir" (Tekin, 2006: 11). Elde stok bulundurmamanın sonuçlarına işletmenin karlı satış fırsatlarını kaçırması, üretiminin durması veya kesintiye uğraması, müşterinin güveninin yitirilmesi gibi durumlar verilebilir.

\subsection{Stok Yönetimi Kavramı ve Stok Yönetiminin Önemi}

Stoklar, ürün maliyetleri içerisinde büyük oranda pay sahibi olması, üretimin kesintisiz olarak yapılabilmesi için önem arz etmesi ve ürünün talep edildiği zamanda karşılanabilmesinde oynadığ yöneticisinin sorumluluk alanıdır. (Top, 2006: 191). Stok yönetimi, muhtemel talebin uygun yer ve zamanda karşılanması için ürün ve malzemelerin en iyi şekilde elde edilme usulü şeklinde tanımlanabilir. Stok yönetimini, üretim ve satış amaçlı tedarik edilen ve üretim sonrasında nihai ürün biçiminde yer alan stokların işletmeye olan maliyetiyle stok bulundurma maliyetinin dengelenmesi esasına dayanır. Buradaki asıl amaç, israfın tamamen ortadan kaldırılmasıdır (Kara, 2014: 50).

Stok yönetimi, "bir üretim surecinin ya da hizmet işlemlerinin tamamlayıcı parçası olan ham maddelerin, yarı işlenmiş malların ve üretim için gerekli diğer materyallerin tedarik kaynaklarının saptanması, satın alınması, taşınması, depolanması ve korunmasına ilişkin faaliyetlerin örgütlenmesi ve kontrol edilmesi” şeklinde ifade edilebilir (Doğan, 1982: 318).

Stok yönetimi, üretim işletmelerinde kaynakların etkin ve verimli kullanması bakımından rekabet avantaj1 sağlayabilmektedir. İşletmelerin stok politikalarının doğru ve uygun planlama ile yapılması önem arz etmektedir. Yöneticiler, işletme kapasite ve politikalarına yönelik seçecekleri stok yönetim uygulamalarıyla maliyetleri minimize ederek kar maksimizasyonunu sağlayabilmektedirler (Gökşen, 2003: 41 - 47).

İşletmelerin ekonomik faaliyetlerine kesintisiz devam edebilmesi, üretim esnekliği ve stok yatırımıyla müşteri memnuniyeti arasındaki dengeye bağlıdır. Stokların yönetimiyse, gerek stok yatırımını minimum seviyelere çeken gerekse üretim esnekliği sağlayarak uygun zaman ve yerde müşteri hizmetini gerçekleştiren bir sistemdir. Bu bağlamda stok yönetimi hem ülke ekonomisinin hem de işletme ekonomisinin dengesi açısından önem arz etmektedir. Stok yönetiminin ana hedefi, işletmenin üretim ve satış koşullarını göz önünde bulundurarak, işletmenin faaliyet alanına göre optimum stok seviyesini belirlemektir. Dolayısıyla işletme maliyetlerini minimize ederek, hizmet kalitesini artırabilecektir (Kara, 2014: 52).

\subsection{Stok Yönetimi ve Kârlılık İlişkisi}

"Kâr, işletmelerin belirli bir dönem sonunda elde ettiği kazanç toplamıdır. Başka bir anlatımla işletmenin belirli bir sürede elde ettiği gelirler ile giderler arasındaki olumlu farktır. Kârlılık ise, en yaygın tarifi ile bir işletmede belirli bir devrede elde edilen kârın o işletmede kullanılan sermayeye oranıdır. Karlılık, bir işletmenin faaliyeti sonucu elde edilen sonuçların bir ölçüsüdür” (Kutluata, 1954: 34).

İşletmelerin faaliyetleri sonucunda elde ettikleri karın yeterli olup olmadığını sadece mali tablolardaki bilgilerle belirlemek oldukça zordur. Nitekim mali tablolar ancak işletmenin belli faaliyet dönemlerinde elde ettiği karı gösterir. İşletmeler faaliyetleri sonucunda kar elde edip/etmediklerini karlılık oranlarından faydalanarak belirleyebilirler. "Kârlılık oranları işletmenin bir dönemde varlıklarına veya öz sermayesine oranla ne ölçüde kar elde ettiğinin göstergeleridir." Karlılık oranlarından işletme çıkar grupları (yatırımcı, hissedar, işveren vd.) yararlanır. "Karlılık ölçülürken: Brüt Kar Oranı, Faaliyet Kar Oranı, Net Kar Oranı, Öz Kaynak Karlılık Oranı, Aktif Karlılık Oranı, Brüt Çalışma Sermayesi Karlılık Oranları kullanılabilir."

İşletmelerin karlılığında önemli rol oynayan kalemlerden birisi de stoklardır. Nitekim stok maliyeti kavramı karlılığı belirleyen en önemli unsurdur. Stok maliyetinin içinde "stok için tahsis edilen sermaye miktarı, depolama giderleri, fire ve kalite kayıpları " mevcuttur. Stok miktarında ve çeşitliliğinde artış söz konusu oldukça işletmenin bu stokları elde edebilecek sermayesinin de artması gerekecektir (Kindik ve Aslan, 2017: 613). Ayrıca karlılık gelirlerin maximize edilip maliyetlerin minimize edilmesi suretiyle artırılabilir (Akgüç, 1998: 153). Yine burada da etkin bir stok yönetimi için finansal oranlardan yararlanılır. Stok yönetimiyle ilgili finansal oranlar (Stok Devir Hızı, Stokların Aktife Oranı, Stokların Net Çalışma Sermayesine Oranı, Stok/Dönen Varlık Oranı, Stok Büyüme Hızı Oranı), stokların net çalışma sermayesinde, brüt çalışma sermayesi içinde ve toplam aktif içindeki ağırlığını ölçmeye yaramaktadır. Stok yönetiminde kullanılan bu oranlardan stok devir hızının karlılıkla doğrudan ilişkisi vardır. "Nitekim stok devir hızı işletmedeki stokların paraya çevrilebilme hızını ortaya koyan bir orandır. Stok devir hızı yüksek olan bir işletme, genellikle daha etkili bir rekabet imkânına sahiptir. Böyle bir firma kar marjını düşürerek satış hacmini genişletebilir. Genişleyen satış hacmi sonucu kar marjındaki düşüşe rağmen işletme karını artırabilir. $\mathrm{Bu}$ durum işletmecilikte -sürümden kazanma- şeklinde ifade edilir. Ancak stok devir hızının artması her zaman işletmeye daha yüksek bir kar sağlanması sonucunu doğurmayabilir. İşletme yeni girdiği piyasada yer edinmek için maliyetine satışlara yer vermiş olup stoklarını hızlı bir şekilde paraya çevirme amacı güdebilir" (Kiracı, 2009: 167).

\section{Literatür incelemesi}

Yapılan literatür taramasında, çalışma sermayesi yönetimi, stok yönetimi ve işletme karlılığı üzerine 1980'li yıllardan bu yana çeşitli çalışmaların yapıldığı gözlemlenmiştir. Konu ile ilgili olarak daha önce yapılmış ampirik çalışmalara ait özet bilgiler şöyledir.

Richard H. ve Parrish M.S., (1986), ABD Alabama'daki Eczacılar Odasına bağlı işletmeler üzerinde yapmış oldukları çalışmada, stokların etkinliği, yatırımların brüt 
getiri oranı ve karlılık arasındaki ilişkiyi incelemişlerdir. Bunun için Stepwise çoklu regresyon modeli ile net kar bağımlı değişken olmak üzere diğer tüm değişkenlerle bir model kurulmuştur. Araştırma sonucunda yatırımların brüt getiri oranı ve stok devir hızının net kârdaki değişimleri en iyi açıklayan değişkenler olduğu bulunmuştur.

Külter ve Demirgüneş (2007) çalışmalarında, BİST'te faaliyette bulunan işletmelerin 1997-2006 dönem verileri kullanarak işletme karlılı̆̆ belirleyicilerini araştırmışlardır. Bütünleşik regresyon analiz yönteminin kullanıldığ çalışma sonucunda karlılığı işletme büyüklüğü ve borç düzeyinin artması azaltırken, çalışma sermayesi yatırımlarıyla Pazar payının genişlemesi azaltmakta olduğu bulgularına ulaşılmıştır.

Albayrak ve Akbulut (2008) çalışmalarında, BİST'te sanayi ve hizmet sektörlerinde faaliyette bulunan işletmelerin 2004-2006 dönem verilerini kullanarak karlılığ1 etkileyen faktörleri araştırmışlardır. Panel veri yöntemi kullanılan çalışma sonucunda, işletme karlılığına en çok etki eden faktörlerin "sermaye yapısı, stok devir hızı, işletme büyüklüğü ve piyasa değeri” olduğu tespit edilmiştir.

Kiracı (2009) çalışmasında, BİST imalat sektöründeki işletmelerin 2002-2006 dönemlerine ait verileri kullanarak işletmelerin stok yönetimiyle karlılık arasındaki ilişkiyi araştırmıştır. Araştırma sonucunda işletmelerin stok devir hızıyla dönem net kârı/net satışlar oranı ve aktif karlılık oranları arasında pozitif yönlü bir ilişki tespit edilmiştir.

Sharma ve Kumar (2011) çalışmalarında, Hindistan'da 2000-2008 y1lları arasında 263 firmanın verilerini kullanarak çalışma sermayesi ile firma karlılığı arasındaki ilişkiyi ölçmeye çalışmışlardır. Araştırma sonucunda, Hindistan şirketlerinde çalışma sermayesi ile firma karlılığı arasında pozitif yönlü bir ilişki olduğu saptanmıştır. Ayrıca stok devir hızı ve alacakların ortalama tahsil süresi ile firma karlılığ1 arasında negatif yönlü bir ilişki olduğu da tespit edilmiştir.

Coşkun ve Kök (2011) çalışmalarında, BİST'te faaliyet gösteren 74 firmanın 1991-2005 yılları arasındaki verilerini kullanarak işletmenin çalışma sermayesi politikalarıyla karlılık arasındaki ilişkiyi incelemişlerdir. Araştırma sonucunda nakit dönüş süresi, alacak tahsil süresi ve stok devir süresi ile karlılık arasında negatif yönlü, borç ödeme süresi ile karlılık arasında pozitif yönlü bir ilişkinin varlığ saptanmıştır.

Aygün (2012) çalışmalarında, BİST’te imalat sektöründe faaliyet gösteren 107 işletmenin 2000-2009 dönem verilerini kullanarak işletmelerin "aktif karlılığı ve alacakların ortalama tahsil süresi, stok devir suresi ve borç ödeme süresi" arasında negatif yönlü ilişkinin olduğu bulgusuna ulaşılmıştır.

Vahid vd. (2012) çalışmalarında, İran borsasında faaliyet gösteren 50 işletmenin 2006-2009 yılları dönem verilerini kullanarak işletme performansıyla çalışma sermayesi yönetimi arasındaki ilişkiyi incelemişler fakat bu iki değişken arasında bir ilişki tespit edilememiştir. Araştırma da "stok devir hızı, borç ödeme süresi ve alacakların tahsil süresini” kısaltma yoluyla işletmelerin karlılıklarını artırabilecekleri bulgusuna ulaşılmıştır.

Kaddumi ve Ramadan (2012), çalışma sermayesi yönetimi ile firma performansı arasındaki ilişkiyi belirlemeyi amaçladıkları çalışmalarında; Amman Menkul Kıymetler Borsası'nda işlem gören 49 sanayi firmasının 2005-2009 dönemi verilerini panel veri regresyon analizi ile test etmişlerdir. Sonuç olarak, alacak ve stok dönüşüm süresi ile kârlılık arasında negatif yönlü bir ilişki tespit edilirken, borç ödeme dönüşüm süresi ile pozitif yönlü bir ilişki bulunmuştur.

Dursun ve Ayrıçay (2013) çalışmalarında, BIST'te faaliyette bulunan 120 üretim ve ticaret işletmesinin verilerini kullanarak çalışma sermayesi ile brüt kar arasındaki ilişkiyi ölçmüşler ve söz konusu değişkenler arasında negatif yönlü bir ilişki tespit etmişlerdir.

Makori ve Jagongo (2013), yine aynı amaç ile Kenya'da Nairobi Menkul Kıymetler Borsası'nda işlem gören 5 imalat ve inşaat firmasının 2003-2012 dönemi verilerini dengeli panel veri analizi (Pearson Korelasyonu ve En Küçük Kareler Regresyon Yöntemi) ile test etmişlerdir. Sonuç olarak, kârlılık ile ortalama alacak dönüşüm süresi ve nakit ticaret süresi arasında negatif; stok dönüşüm süresi ve borç ödeme dönüşüm süresi arasında pozitif yönlü bir ilişki bulunmuştur. Ayrıca finansal kaldıracın, satışlardaki büyümenin, cari oranın ve firma büyüklügüünün de kârlılık üzerinde önemli bir etkiye sahip olduğu belirtilmiştir.

Mumtaz vd. (2013), çalışma sermayesi yönetimiyle performans arasındaki ilişkiyi incelemeyi amaçlamıştır. 2005-2010 döneminde Karaçi Menkul Kiymetler Borsası'nda işlem gören 22 kimya firmasının finansal tablolarından elde edilen veriler yardımıyla analiz gerçekleştirilmiştir. Çalışma sermayesini temsilen alacak dönüşüm süresi, stok dönüşüm süresi, satıșlar, firma büyüklüğü, kaldıraç oranı, stoklar ve özkaynaklar kullanılırken firma performansını ölçmek için ise bağımlı değişken olarak aktif kârlılık alınmıştır. Sonuç olarak aktif kârlılığ1 ile firma büyüklüğü, stok dönüşüm süresi ve satışlar arasında pozitif bir ilişki tespit edilirken, alacak dönüşüm süresi ile arasında negatif yönlü bir ilişki bulunmuş.

Enqvist vd. (2014), yine aynı amaç doğrultusunda Finlandiya'da faaliyette bulunan 1136 firmanın 1990-2008 dönemi verileri yardımıyla regresyon analizi uygulamıştır. Kârlılığın ölçütü olarak hem aktif kârlılığı hem de brüt faaliyet kârlılığı kullanılmıştır. Kârlılık ile nakit ticaret süresi, stok dönüşüm süresi ve firma büyüklüğü arasında negatif; cari oran ile arasında pozitif yönlü bir ilişki tespit edilmiştir.

Agha (2014), Pakistan'da Karachi Borsa'sında faaliyet gösteren Glaxo Smith Kline ilaç şirketine ait 1996-2011 yıllarına ait veriler kullanarak çalışma sermayesinin karlılık üzerindeki etkisini incelemiştir. Araştırma sonucunda çalışma sermayesinin karlılık üzerinde önemli etkisi olduğu belirlenmiştir. Araştırmada işletmeler stok devir hızlarını, alacak devir hızlarını minimize eder borç devir hızlarını düşürür ise karlılıklarında pozitif yönde değişimler olacağı sonucuna ulaşılmıştır.

Ayub (2015), çalışma sermayesi yönetiminin kârlılık üzerindeki etkisini araştırmayı amaçladığı çalışmasında; Karaçi Menkul Kıymetler Borsası'nda işlem gören 138 tekstil firmasının 1999-2007 dönemi verilerini kullanmıştır. Çalışma sermayesinin yönetiminde ortalama alacak dönüşüm süresi, stok dönüşüm süresi, borç ödeme dönüşüm süresi, nakit ticaret süresi ve cari oran alınırken, kârlılık 
ölçümünde ise net faaliyet kârlılığı kullanılmıştır. Yapılan regresyon analizi sonucunda, kontrol değişkeni olan brüt çalışma sermayesi devir hızı ile kârlılık arasında pozitif yönlü zayıf bir ilişki bulunmuştur

\section{Araştırma Yöntemi Ve Analiz Sonuçları}

\subsection{Araştırmanın Amacı}

Çalışma, işletmelerin finansal durumunu etkileyen stok yönetiminin işletmenin karlılı̆̆ üzerindeki etkisini finansal oranlar yardımıyla ölçmeyi amaçlamıştır. $\mathrm{Bu}$ amaç doğrultusunda stok yönetimine ilişkin oranlar ile karlılık oranları arasındaki ilişki regresyon ve korelasyon analizleri ile çözümlenerek anlamlı bir ilişkinin olup/olmadığı ve bu ilişkiyi en iyi şekilde açıklayan oranlar tespit edilmeye çalışılmıştır.

\subsection{Araştırma Yöntemi ve Kullanılan Değişkenler}

Araştırmada elde edilen verilerin açıklanmasına yönelik açıklayıcı istatistiksel yöntemlerle stok ve karlılık oranları arasındaki matematiksel ilişkiyi belirlemeye yönelik regresyon analizi ile ilişki yönü ve kuvvetini belirlemeye yönelik korelasyon analizi yapılacaktır.

Regresyon analizi; değişkenler arasındaki matematiksel ilişkiyi modellemek ve incelemek amacıyla kullanılan istatistiksel bir yöntemdir (Gamgam ve Altunkaynak, 2017; 11)

Regresyon analizinde bir veya daha fazla bağımsız (açıklayıcı) değişkenin değerlerine dayanarak bağımlı (açıklanan) değişkenin ortalama değerleri regresyon denklemi elde edilir. $\mathrm{Bu}$ denklem istatistiksel olarak anlamlı olduğu zaman bağımsız değişkenlerdeki değişim bilindiğinde bağımlı değişken tespit edilebilir. Araştırma kapsamındaki işletmelerin stok yönetimine ilişkin ilgili finansal oranları ile karlılık oranları arasındaki ilişkiyi regresyon analizini kullanarak açıklık getirmek mümkündür. Araştırmada stok yönetimi ve genel olarak karlılı̆̆1 etkileyen oranları da içeren bir "regresyon modeli" kurularak işletme karlılığı açıklanmaya çalışılmıştır. Regresyon modelinde karlılık oranlarl "bağımlı değişken" aktif karlılık oranı, brüt karlılık oranı ve öz kaynak karlılık oranı olarak kullanılmaktadır. Modelde "bağımsız değişken" stok devir hızı, stokların aktif ve dönen varlık içindeki ağırlığı ve stokların büyüme hızı kullanılarak karlılık açıklanmaya çalışılmıştır.

Korelasyon analizi ise değişkenler arasındaki ilişkinin derecesini gösterir. Ayrıca çalışmada bağımsız değişkenlerin arasındaki çoklu bağlantıya işaret eden VIF (Variance Inflation Factor) değerlerine bakılmıştır. VIF değeri yüksek olan değişkenler çoklu bağıntı sorunu teşkil ettiği için modelde VIF değeri yüksek olan değişkenler modelden çıkarılmıştır.

Korelasyon analizi, “aralık ve oran düzeyinde ölçülmüş iki değişken arasında ilişki ve bağımlılık olup olmadığını, ilişki ve bağımlılık var ise yönünü ve gücünü göstermek amacıyla çok yaygın olarak kullanılan bir analiz tekniğidir" (Yazıcıoğlu, Erdoğan, 2004: 224). "İlişkinin yönü ve gücü korelasyon katsayısı "r" ile gösterilir. Eğer bir değişkenin artan değerleri, diğer değişkenin artan değerleri ile doğrusal bicimde ilişkili ise, değişkenler pozitif ilişkilidir. Ĕger bir değişkenin artan değerleri, diğer değişkenin azalan değerleri ile doğrusal bicimde ilişkili ise değişkenler negatif ilişkidir (Akgül ve Çevik, 2003: 356) Korelasyon katsayısı $-1<r<1$ arasında değerler alabilir. Korelasyon katsayısı "r" (0,0-0,25) "Çok Zayıf ilişki”, $(0,26-0,49)$ "Zayıf İlişkì", $(0,50-0,69)$ “Orta ilişki”, $(0,70-0,89)$ "Yüksek ilişki”" ve $(0,90-1,00)$ "Çok yüksek ilişki” ölçütlerine göre yorumlanabilir. $\mathrm{Bu}$ durumda kısaca korelasyon katsayısı "1"e yaklaştıkça ilişki kuvvetlenir. Katsayı "0"olması durumunda ise her iki değişken arasında herhangi bir ilişkinin olmadığı anlamına gelmektedir" (Altunışık vd., 2001: 176).

Araştırmada korelasyon analizi ile stok ve karlılık oranları arasındaki ilişkinin yönü ve derecesi tespit edilecektir. Regresyon ile korelasyon analizi arasındaki temel farklılık; korelasyon analizinde, değişkenlerden herhangi birinin, diğerini etkileyip etkilemediği araştırılırken; regresyon analizinde ise bağımsız değişkenin, bağımlı değişkeni etkilemesi araştırılır. (Karagöz, 2016; 693)

Araştırmada kullanılan değişkenler (2013-2018) dönemi içerisinde faaliyette bulunan ve finansal tabloları Kamu Aydınlatma Platformunda (KAP) yayınlan imalat sektöründeki 140 işletmeden oluşmaktadır. İmalat sektörünün alt sektörlerine ilişkin bilgiler ve işletme sayıları Tablo 1'de verilmiştir.

Tablo 1: Araştırmada Yer Alan İşletmelerin Faaliyette

Bulunduğu Sektörlere İlişkin Bilgiler

\begin{tabular}{lc}
\hline Yer Alan İşletmelerin Alt Sektörleri & $\mathbf{2 0 1 3 - 2 0 1 8}$ \\
\hline Gıda, İçki ve Tütün Sektörü & 22 \\
\hline Dokuma Giyim Eşyası Ve Deri Sektörü & 19 \\
\hline Orman Ürünleri ve Mobilya Sektörü & 4 \\
\hline Kâğıt ve Kâğı̈ Ürünleri Sektörü & 13 \\
\hline Kimya, Petrol, Kauçuk ve Plastik Sektörü & 24 \\
\hline Taş ve Toprağa Dayalı Sektör & 22 \\
\hline Metal Ana Sanayi Sektörü & 11 \\
\hline Metal Eşya, Makine ve Gereç Sektörü & 24 \\
\hline Diğer İmalat Sektörü & 1 \\
\hline \multicolumn{2}{c}{ Toplam } \\
\hline
\end{tabular}

Tabloda belirtilen sektörlerdeki işletmelerin yayınlanan finansal tablolarından elde edilen finansal oranlar Tablo 2' de gösterilmiştir.

Tablo 2: Araştırmada Kullanılan Oranlar ve Kodları

\begin{tabular}{|c|c|c|c|}
\hline \multicolumn{4}{|c|}{ Oranlar } \\
\hline \multicolumn{2}{|c|}{ Stok Yönetim Oranları } & \multicolumn{2}{|c|}{ Karlııkla İlgili Oranları } \\
\hline Stok Devir Hızı & SDH & Brüt Kar Oranı & BKO \\
\hline Stok Aktif Oranı & SAO & Esas Faaliyet Kar Oranı & EFKO \\
\hline $\begin{array}{l}\text { Stokların Net } \\
\text { Çalışma Sermayesine } \\
\text { Oranı }\end{array}$ & SNÇSO & Aktif Karlılığ1 & AKO \\
\hline $\begin{array}{l}\text { Stokların Dönen } \\
\text { Varlıklara Oranı }\end{array}$ & SDV & $\begin{array}{l}\text { Brüt Çalışma Sermayesi } \\
\text { Karlılık Oranı }\end{array}$ & BÇSKO \\
\hline $\begin{array}{l}\text { Stok Büyüme Hızı } \\
\text { Oranı }\end{array}$ & SBHO & Öz Kaynak Karlılık Oranı & ÖKKO \\
\hline
\end{tabular}

İşletmelerin Tablo 2'de belirtilen stok ve karlılık oranları hesaplanarak araştırmada her bir dönem için 1400 adet, toplamda ise 7000 adet işletme verisi kullanılmıştır.

\section{Bulgular ve Yorum}

Araştırmada elde edilen verilerin derlenmesinde ve istatistiksel analizlerde Minitab18.0 paket programı ve 
SPPS 22.0 istatistik programı kullanılmıştır. Öncelikle değişkenlerin normal dağılım gösterip göstermediği araştırılarak değişkenlere ilişkin elde edilen bulgular Tablo 3'de verilmiştir.

Tablo 3: Değişkenlerin Normallik Test Sonuçları

\begin{tabular}{cccc}
\hline \multirow{2}{*}{ Oranlar } & \multicolumn{3}{c}{ Kolmogorov-Smirnov } \\
\cline { 2 - 4 } & $\begin{array}{c}\text { Test } \\
\text { İstatistiği }\end{array}$ & $\begin{array}{c}\text { Serbestlik } \\
\text { Derecesi }\end{array}$ & $\begin{array}{c}\text { Önem } \\
\text { Derecesi } \\
(\mathbf{p})\end{array}$ \\
\hline Stok Devir Hızı & 0.504 & 840 & 0.000 \\
\hline Stok /Aktif Oranı & 0.093 & 840 & 0.000 \\
\hline $\begin{array}{c}\text { Stok /Net Chalışma } \\
\text { Sermayesi }\end{array}$ & 0.358 & 840 & 0.000 \\
\hline Stok/ Dönen Varlıklar & 0.061 & 840 & 0.000 \\
\hline Stok Büyüme Hızı Oranı & 0.495 & 840 & 0.000 \\
\hline Brüt Kar Oranı & 0.163 & 840 & 0.000 \\
\hline Esas Faaliyet Kar Oranı & 0.200 & 840 & 0.000 \\
\hline Aktif Karlılık & 0.082 & 840 & 0.000 \\
\hline $\begin{array}{c}\text { Brüt Çalışma Sermayesi } \\
\text { Karlılığ } 1\end{array}$ & 0.133 & 840 & 0.000 \\
\hline Öz Kaynak Karlılığ1 & 0.509 & 840 & 0.000 \\
\hline Tayn & & &
\end{tabular}

Tablo incelendiğinde hesaplanan oranlara ilişkin Kolmogorov-Smirnov test sonuçları ve testlere ilişkin anlamlılık düzeyi incelendiğinde $\mathrm{p}<0,05$ olduğu için değişkenlerin normal dağılım göstermediği söylenebilir. $\mathrm{Bu}$ nedenle korelasyon analizinde spearman sıra korelasyon analizi yapılacaktır. Kullanılan değişkenlere ilişkin bazı istatistiki bilgiler Tablo 4'te verilmiştir.

Tablo 4: Hesaplanan Finansal Oranlara İlişkin Tanımlayıcı İstatistikler

\begin{tabular}{cccc}
\hline Oranlar & Ortalama & $\begin{array}{c}\text { Standart } \\
\text { Sapma }\end{array}$ & Medyan \\
\hline SDH & 6,91 & 117,89 & 1,07 \\
\hline SAO & 0,16 & 0,11 & 0,14 \\
\hline SNÇS & 0,55 & 12,40 & 0,55 \\
\hline SDV & 0,32 & 0,19 & 0,29 \\
\hline SBHO & 2,81 & 70,66 & 0,14 \\
\hline BKO & 0,22 & 0,22 & 0,21 \\
\hline EFKO & 0,08 & 0,20 & 0,08 \\
\hline AKO & 0,04 & 0,10 & 0,03 \\
\hline BÇSKO & 0,07 & 0,25 & 0,06 \\
\hline ÖKKO & $-58,1$ & 1685,7 & 0,10 \\
\hline
\end{tabular}

Tablo incelendiğinde tüm dönemlere ilişkin finansal oranların ortalama, standart sapma ve medyan değerleri görülmektedir. $\mathrm{Bu}$ oranlardan öz kaynak karlılığının standart sapmasının $(1685,7)$ çok yüksek ve ortalamasının $(-58,1)$ negatif olduğu tespit edilirken diğer finansal oranların pozitif olduğu tespit edilmiştir.

\subsection{Regresyon Analizine İlişkin Bulgular}

Araştırmada her dönem için ayrı ayrı hesaplan regresyon analizine ilişkin sonuçlar tablolar halinde sunulmuştur. İmalat sektöründe yer alan işletmelerin finansal oranları arasındaki matematiksel ilişki regresyon analizi ile tespit edilmeye çalışılmış ve regresyon analizinde forward selection yöntemi uygulanmıştır. Forward selection yöntemi öncelikle en iyi tek değişkenli model ile başlanarak her seferinde en yüksek katkıyı sağlayacak değişken ilave edilerek uygulanan bir yöntemdir. Yani bir değişken ilavesi ile regresyonun hata kareler toplamında meydana gelen değişmenin (küçülmenin)önemli olup olmadığına bakılır. $\mathrm{Bu}$ işlem eklenen değişkenin katsayısının önemsiz olması durumunda sona erdirilir. Bu yöntemle elde edilen anlamlı modellere yer verilerek sonuçlar açıklanmaya çalışılmıştır. Her bir bağımlı değişken için 2013 yılı verileri ile oluşturulan modeller aşağıdaki gibidir.

Tablo 5: 2013 Verileri İçin Karlılık Oranı ile Stok Yönetim Oranları Arasındaki Regresyon Analizi Sonuçları ve Modeli

\begin{tabular}{ccccc}
\hline Bağımsız Değişkenler & Katsayılar & $\mathbf{t}$ & $\mathbf{p}$ & VIF \\
\hline Sabit & 0,750 & 4,65 & 0,000 & \\
\hline Stok Aktif Oranı & 0,257 & 2,44 & 0,016 & 2,39 \\
\hline Stok Dönen Varlık Oranı & $-0,282$ & $-3,92$ & 0,000 & 2,43 \\
\hline Stok Büyüme Hızı Oranı & $-0,008$ & $-1,33$ & 0,018 & 2,04 \\
\hline$F=6,90, \quad P=0,000$, & $R^{2}=\% 13,20$, & D. W. $S=1,793$ \\
\hline Aktif Karlıık Oranı $=\mathbf{0 , 7 5 0}+\mathbf{0 , 2 5 7 . S A O}$ & $\mathbf{- 0 , 2 8 2 . S D V ~} \mathbf{- ~ 0 , 0 0 8 . S B H O}$ \\
\hline Bağımsız Değişkenler & Katsayılar & $\mathbf{t}$ & $\mathbf{p}$ & VIF \\
\hline Sabit & 0,205 & 9,00 & 0,000 \\
\hline Stok Aktif Oranı & 0,470 & 3,18 & 0,002 & 2,35 \\
\hline Stok Dönen Varlık Oranı & $-0,295$ & $-2,97$ & 0,004 & 2,34 \\
\hline
\end{tabular}

$F=4,42 ; \quad P=0,005 ; \quad R^{2}=\% 8,89 ; \quad$ D.W.S. $=2,043$

\begin{tabular}{|c|c|c|c|c|}
\hline \multicolumn{5}{|c|}{ Brüt Karlılık Oranı $=0,205+$ 0,470.SAO $-0,295 . S D V$} \\
\hline Bağımsız Değişkenler & Katsayılar & $\mathbf{t}$ & $\mathbf{p}$ & VIF \\
\hline Sabit & 0,114 & 4,58 & 0,000 & \\
\hline Stok Aktif Oranı & 0,609 & 3,79 & 0,000 & 2,34 \\
\hline Stok Dönen Varlık Oranı & $-0,521$ & $-4,80$ & 0,000 & 2,34 \\
\hline
\end{tabular}

$F=11,54 ; \quad P=0,000 ; \quad R^{2}=\% 14,42 ; \quad$ D.W.S. $=1,965$

Esas Faaliyet Karlıık Oranı = 0,114 + 0,609.SAO - 0,521.SDV

\begin{tabular}{ccccc}
\hline Bağımsız Değişkenler & Katsayılar & $\mathbf{t}$ & $\mathbf{p}$ & VIF \\
\hline Sabit & 0,164 & 4,04 & 0,000 & \\
\hline Stok Aktif Oranı & 0,655 & 2,51 & 0,013 & 2,34 \\
\hline Stok Dönen Varlık Oranı & $-0,739$ & $-4,19$ & 0,000 & 2,34 \\
\hline
\end{tabular}

$F=9,26 ; \quad P=0,000 ; \quad R^{2}=\% 11,91 ; \quad$ D.W.S. $=1,875$

BÇSKO = 0,164 + 0,655.SAO - 0,739.SDV

Aktif karlılık oranındaki değişimleri açıklamak için kurulan regresyon modelinde, stok aktif oranı aktif karlılığa pozitif yönde etki etmektedir yani stok aktif oranındaki bir birimlik artış aktif karlılık oranında 0,257 birim artışa neden olacaktır. Stok dönen varlık oranı ile stok büyüme hızı oranı negatif yönde etki yapmaktadır. $\mathrm{Bu}$ iki orandaki bir birimlik artış ise aktif karlılık oranına sırasıyla 0,282 birim ve 0,008 birim azalışa neden olacaktır. Stok yönetimiyle ilgili diğer oranların modelde yer almadığ Modelinde kullanılan bağımsız değişkenlerin aktif karlılı̆̆ı açıklama oranının \%13,20 olduğu anlamlı bir model tespit edilmiştir.

$>$ Brüt karlılık oranındaki değişimleri açıklamak için kurulan regresyon modelinde, stok aktif oranının brüt karlılığa pozitif yönde etki etmektedir yani stok aktif oranındaki bir birimlik artış brüt karlılık oranında 0,470 
birim artışa neden olacaktır. Stok dönen varlık oranın negatif yönde etki etmektedir yani stok dönen varlık oranındaki bir birimlik artış brüt karlılık oranında 0,295 birim azalışa neden olacaktır. Stok yönetimiyle ilgili diğer oranların modelde yer almadığı görülmektedir. Regresyon Modelinde kullanılan bağımsız değişkenlerin brüt karlılı̆̆ açıklama oranı \%8,89olduğu anlamlı bir model tespit edilmiştir.

$>$ Esas faaliyet karlılık oranındaki değişimleri açıklamak için kurulan regresyon modelinde, stok aktif oranının esas faaliyet karlılığına pozitif yönde etki etmektedir. Yani stok aktif oranındaki bir birimlik artış esas faaliyet karlılık oranında 0,609 birim artışa neden olacaktır; stok dönen varlık oranın negatif yönde etki yapmaktadır. Bu durum stok dönen varlık oranındaki bir birimlik artışın esas faaliyet karlılık oranında 0,521 birimlik azalışa sebep olacağını ifade etmektedir. Stok yönetimiyle ilgili diğer oranlar modelde yer almiyor. Regresyon Modelinde kullanılan bağımsız değişkenlerin esas faaliyet karlılık oranını \%14,42oranında açıklamakta ve model anlamlıdır.

$>$ Brüt Çalışma sermayesi karlılık oranındaki değişimleri açıklamak için kurulan regresyon modelinde, stok aktif oranının brüt karlılığa pozitif yönde etki etmektedir. Yani stok aktif oranındaki bir birimlik artış brüt çalışma sermayesi karlılık oranında 0,655 birim artışa neden olacaktır. Stok dönen varlık oranın negatif yönde etki yapmaktadır. Yani stok dönen varlık oranındaki bir birimlik artış brüt çalışma sermayesi karlılık oranında 0,739 birim azalışa neden olacaktır. Stok yönetimiyle ilgili diğer oranların modelde yer almadığ görülmektedir. Regresyon Modelinde kullanılan bağımsız değişkenlerin brüt çalışma sermayesi karlılığı açıklama oranının \%11,91olduğu anlamlı bir model tespit edilmiştir.

$>$ Öz kaynak karlılık oranı ile stok yönetimi oranları arasında anlamlı bir modelin oluşmadığı tespit edilmiştir.

Tablo 6: 2014 Verileri İçin Karlılık Oranı ile Stok Yönetim Oranları Arasındaki Regresyon Analizi Sonuçları ve Modeli

\begin{tabular}{ccccc}
\hline Bağımsız Değişkenler & Katsayılar & $\mathbf{t}$ & $\mathbf{p}$ & VIF \\
\hline Sabit & 0,073 & 4,31 & 0,000 & \\
\hline Stok Aktif Oranı & 0,246 & 2,33 & 0,021 & 2,29 \\
\hline $\begin{array}{c}\text { Stok Dönen Varlık } \\
\text { Oranı }\end{array}$ & $-0,196$ & $-2,75$ & 0,007 & 2,29 \\
\hline$F=3,41, \quad P=0,019 ; R^{2}=\% 7,00 ;$ & D. W. W. $=2,017$ \\
\hline \multicolumn{4}{c}{ Aktif Karlılık Oranı $=\mathbf{0 , 0 7 3}+\mathbf{0 , 2 4 6 . S A O ~} \mathbf{- 0 , 1 9 6 . S D V}$} \\
\hline
\end{tabular}

$>$ Aktif karlılık oranındaki değişimleri açıklamak için kurulan regresyon modelinde, stok aktif oranının aktif karlılığı pozitif yönde etki etmektedir yani stok aktif oranındaki bir birimlik artıș aktif karlılık oranında 0,246 birim artışa neden olacaktır. Stok dönen varlık oranı negatif yönde etki etmektedir. Yani stok dönen varlık oranındaki bir birimlik artış aktif karlılık oranında 0,196 birim azalışa neden olacaktır. Stok yönetimiyle ilgili diğer oranların modelde yer almadığı görülmektedir. Regresyon Modelinde kullanılan bağımsız değişkenlerin aktif karlılığı açıklama oranın \%7,0 olduğu anlamı bir model tespit edilmiştir.
2014 y1lı için diğer karlılık oranları ile stok yönetimi oranları arasında anlamlı bir modelin oluşmadığı tespit edilmiştir.

Tablo 7: 2015 Verileri İçin Karlılık Oranı ile Stok Yönetim Oranları Arasındaki Regresyon Analizi Sonuçları ve Modeli

\begin{tabular}{ccccc}
\hline Bağımsız Değişkenler & Katsayılar & $\mathbf{t}$ & $\mathbf{p}$ & VIF \\
\hline Sabit & 0,067 & 4,33 & 0,000 & \\
\hline Stok Aktif Oranı & 0,203 & 1,98 & 0,045 & 2,52 \\
\hline Stok Dönen Varlık Oranı & $-0,196$ & $-2,80$ & 0,006 & 2,52 \\
\hline
\end{tabular}

$F=3,96, \quad P=0,021 ; R^{2}=\% 5,47 ; \quad$ D.W.S. $=2,068$

Aktif Karlıık Oranı $=0,067+0,203 . S A O-0,196 . S D V$

> Aktif karlılık oranındaki değişimleri açıklamak için kurulan regresyon modelinde, stok aktif oranının aktif karlılığ oranındaki bir birimlik artış aktif karlılık oranında 0,203 birim artışa neden olacaktır. Stok dönen varlık oranı negatif yönde etki etmektedir. Yani stok dönen varlık oranındaki bir birimlik artış aktif karlılık oranında 0,196 birim azalışa neden olacaktır Stok yönetimiyle ilgili diğer oranların modelde yer almadığı görülmektedir. Regresyon Modelinde kullanılan bağımsız değişkenlerin aktif karlılığı açıklama oranın \%5,47 olduğu anlamı bir model tespit edilmiştir.

$>2015$ yılı için diğer karlılık oranları ile stok yönetimi oranları arasında anlamlı bir modelin oluşmadığı tespit edilmiştir.

Tablo 8: 2016 Verileri İçin Karlılık Oranı ile Stok Yönetim Oranları Arasındaki Regresyon Analizi Sonuçları ve Modeli

\begin{tabular}{ccccc}
\hline Bağımsız Değişkenler & Katsayılar & $\mathbf{t}$ & $\mathbf{p}$ & VIF \\
\hline Sabit & 0,245 & 11,09 & 0,000 & \\
\hline $\begin{array}{c}\text { Stok Dönen Varlıklara } \\
\text { Oranı }\end{array}$ & $-0,040$ & $-3,15$ & 0,002 & 1,04 \\
\hline Stok Aktif Oranı & 0,186 & 1,95 & 0,045 & 1,45 \\
\hline Stok Büyüme Hizı Oranı & 0,080 & 3,22 & 0,002 & 1,12 \\
\hline
\end{tabular}

$F=5,20 ; \quad P=0,001 ; \quad R^{2}=\% 13,35 ; \quad D . W . S .=1,825$

\begin{tabular}{ccccc}
\hline \multicolumn{2}{c}{ Brüt Karlılık Oranı $=\mathbf{0 , 2 4 5}$} & $\mathbf{- 0 , 0 4 0 . S D H}+\mathbf{0 , 1 8 6 . S A O}$ & $\mathbf{0 , 0 8 0 . S B H O}$ \\
\hline Bağımsız Değișkenler & Katsayılar & $\mathbf{t}$ & $\mathbf{p}$ & VIF \\
\hline Sabit & 0,084 & 4,67 & 0,000 & \\
\hline $\begin{array}{c}\text { Stok Dönen Varlıklara } \\
\text { Oranı }\end{array}$ & $-0,145$ & $-2,84$ & 0,005 & 1,58 \\
\hline Stok Büyüme Hızı Oranı & 0,102 & 3,82 & 0,000 & 1,11 \\
\hline
\end{tabular}

$F=5,93 ; \quad P=0,001 ; \quad R^{2}=\% 11,58 ; \quad$ D.W.S. $=2,072$

Esas Faaliyet Karlılık Oranı = 0,084- 0,145.SDH + 0,102.SBHO

Brüt karlılık oranındaki değişimleri açıklamak için kurulan regresyon modelinde, stok aktif oranını ve stok büyüme hızı oranı brüt karlılığa pozitif yönde etki etmektedir. Bu iki orandaki bir birimlik artışın sırasıyla brüt karlılık oranında 0,186 birim ve 0,080 birim artışa neden olacaktır. Stok dönen varlık oranın negatif yönde etki etmektedir. Bu durum stok dönen varlık oranındaki bir birimlik artış bürüt karlılık oranında 0,040 birim azalışa neden olacaktır. Stok yönetimiyle ilgili diğer oranlar modelde yer almamaktadır. Regresyon 
Modelinde kullanılan bağımsız değişkenlerin brüt çalışma sermayesi karlılığı açıklama oranının \%13,35 olduğu anlamlı bir model belirlendi.

$>$ Esas faaliyet karlılık oranındaki değişimleri açıklamak için kurulan regresyon modelinde, stok büyüme hızı oranının esas faaliyet karlılığına pozitif yönde etki etmektedir yani bu orandaki bir birimlik artış esas faaliyet karlılık oranında 0,102 birim artışa neden olmaktadır. Stok dönen varlık oranın negatif yönde etki ettiği için bu orandaki bir birimlik artış ise esas faaliyet karlılık oranında 0,145 birim azalışa neden olacaktır. Stok yönetimiyle ilgili diğer oranların modelde yer almadığı görülmektedir. Regresyon Modelinde kullanılan bağımsız değişkenlerin esas faaliyet karlılık oranını \%11,58 oranında açıkladığı ve modelin anlamlı olduğu tespit edilmiştir.

$>2016$ yılı için diğer karlılık oranları ile stok yönetimi oranları arasında anlamlı bir modelin oluşmadığı tespit edilmiştir.

Tablo 9: 2017 Verileri İçin Karlılık Oranı ile Stok Yönetim Oranları Arasındaki Regresyon Analizi Sonuçları ve Modeli

\begin{tabular}{ccccc}
\hline Bağımsız Değişkenler & Katsayılar & $\mathbf{t}$ & $\mathbf{p}$ & VIF \\
\hline Sabit & 0,225 & 10,70 & 0,000 & \\
\hline Stok Devir Hızı Oranı & $-0,034$ & $-2,86$ & 0,005 & 1,00 \\
\hline Stok Aktif Oranı & 0,214 & 2,46 & 0,015 & 1,00 \\
\hline
\end{tabular}

$F=6,71 ; \quad P=0,002 ; \quad R^{2}=\% 8,93 ; \quad$ D.W.S. $=1,909$

Brüt Karlılık Oranı = 0,225 - 0,034.SDH + 0,214.SAO

> Brüt karlılık oranındaki değişimleri açıklamak için kurulan regresyon modelinde, stok aktif oranını brüt karlılığa pozitif yönde etki etmektedir. Yani stok aktif oranındaki bir birimlik artış brüt karlılık oranında 0,214 birim artışa neden olacaktır. Stok devir hızı oranı negatif yönde etki etmektedir. Bu orandaki bir birimlik artış ise brüt karlılıkta 0,034 birim azalışa neden olacaktır. Stok yönetimiyle ilgili diğer oranların modelde yer almadığı görülmektedir. Regresyon Modelinde kullanılan bağımsız değişkenlerin brüt çalışma sermayesi karlılığı açıklama oranının \%8,93 olduğu anlamlı bir model tespit edilmiştir.

$>2017$ yılı için diğer karlılık oranları ile stok yönetimi oranları arasında anlamlı bir modelin oluşmadığı tespit edilmiştir.

Tablo 10: 2018 Verileri İçin Karlılık Oranı ile Stok Yönetim Oranları Arasındaki Regresyon Analizi Sonuçları ve Modeli

\begin{tabular}{ccccc}
\hline Bağımsız Değişkenler & Katsayılar & $\mathbf{t}$ & $\mathbf{p}$ & VIF \\
\hline Sabit & 0,038 & 1,93 & 0,045 & \\
\hline Stok Dönen Varlık Oranı & $-0,214$ & $-2,60$ & 0,010 & 2,58 \\
\hline Stok Büyüme Hızı Oranı & 0,099 & 5,22 & 0,000 & 1,06 \\
\hline
\end{tabular}

$F=11,31, \quad P=0,000 ; R^{2}=\% 19,96 ; \quad$ D.W.S. $=1,989$

\begin{tabular}{ccccc}
\hline \multicolumn{4}{c}{ Aktif Karlıık Oranı $=\mathbf{0 , 0 3 8}-\mathbf{0 , 2 1 4 . S D V}+\mathbf{0 , 0 9 9 . S B H O}$} \\
\hline Bağımsız Değişkenler & Katsayılar & $\mathbf{t}$ & $\mathbf{p}$ & VIF \\
\hline Sabit & 0,323 & 8,88 & 0,000 & \\
\hline Stok Aktif Oranı & 0,512 & 2,82 & 0,005 & 2,80 \\
\hline Stok Devir Hızı Oranı & $-0,069$ & $-4,38$ & 0,000 & 1,14 \\
\hline Stok Dönen Varlık Oranı & $-0,295$ & $-2,57$ & 0,011 & 2,86 \\
\hline
\end{tabular}

$F=7,05 ; \quad P=0,000 ; \quad R^{2}=\% 17,27 ; \quad D . W . S .=1,857$

\begin{tabular}{ccccc}
\hline \multicolumn{3}{c}{ Brüt Karlılık Oranı $=\mathbf{0 , 3 2 3}+\mathbf{0 , 5 1 2 . S A O}$} & $\mathbf{- 0 , 0 6 9 . S D H}-\mathbf{0 , 2 9 5 . S D V}$ \\
\hline Bağımsız Değişkenler & Katsayılar & $\mathbf{t}$ & $\mathbf{p}$ & VIF \\
\hline Sabit & 0,082 & 2,90 & 0,004 & \\
\hline Stok Dönen Varlık Oranı & $-0,268$ & $-2,28$ & 0,024 & 2,60 \\
\hline Stok Büyüme Hızı Oranı & 0,126 & 4,67 & 0,000 & 1,06 \\
\hline
\end{tabular}

$F=8,28 ; \quad P=0,000 ; \quad R^{2}=\% 19,70 ; \quad D . W . S .=1,914$

Esas Faaliyet Karlılık Oranı = 0,082- 0,268.SDV+ 0,126.SBHO

> Aktif karlılık oranındaki değişimleri açıklamak için kurulan regresyon modelinde, stok büyüme hızı oranı aktif karlılığa pozitif yönde etki etmektedir. Bu orandaki bir birimlik artış aktif karlılık oranında 0,099 birim artışa neden olacaktır. Stok dönen varlık oranı negatif yönde etki etmektedir. Bu orandaki bir birimlik artış ise aktif karlılık oranında 0,214 birim azalışa neden olacaktır. Stok yönetimiyle ilgili diğer oranların modelde yer almadiğı görülmektedir. Regresyon Modelinde kullanılan bağımsız değişkenlerin aktif karlılığı açıklama oranın \%19,96 olduğu anlamı bir model tespit edilmiştir.

$>$ Brüt karlılık oranındaki değişimleri açıklamak için kurulan regresyon modelinde, stok aktif oranının brüt karlılığa pozitif yönde etki etmektedir. Bu orandaki bir birimlik artış brüt karlılık oranında 0,512 birim artışa neden olacaktır. Stok dönen varlık oranı ve stok devir hızı oranı negatif yönde etki etmektedir. Bu oranlardaki bir birimlik artış ise sırasıyla aktif karlılık oranında 0,069 birim ve 0,295 birim azalışa neden olacaktır. Stok yönetimiyle ilgili diğer oranların modelde yer almadığı görülmektedir. Regresyon Modelinde kullanılan bağımsız değişkenlerin brüt karlılığı açıklama oranın \%17,27 olduğu anlamlı bir model tespit edilmiştir.

$>$ Esas faaliyet karlılık oranındaki değişimleri açıklamak için kurulan regresyon modelinde, stok büyüme hızı oranı esas faaliyet karlılığına pozitif yönde etki etmektedir. Bu orandaki bir birimlik artış esas faaliyet karlılık oranında 0,126 birim artışa neden olacaktır. Stok dönen varlık oranın negatif yönde etki etmektedir. $\mathrm{Bu}$ orandaki bir birimlik artıș ise aktif karlılık oranında 0,268 birim azalışa neden olacaktır. Stok yönetimiyle ilgili diğer oranların modelde yer almadığı görülmektedir. Regresyon Modelinde kullanılan bağımsız değişkenlerin esas faaliyet karlılık oranını \%19,70 oranında açıkladığı ve modelin anlamlı olduğu tespit edilmiştir.

$>2018$ yılı için diğer karlılık oranları ile stok yönetimi oranları arasında anlamlı bir modelin oluşmadığı tespit edilmiştir

\subsection{Korelasyon Analizine İlişsin Bulgular}


Araştırmada 2013-2018 dönemini kapsayan korelasyon analizi sonuçları tablolar halinde sunularak imalat sektöründe yer alan işletmelerin finansal oranlar arasındaki ilişkinin önem derecesi açıklanmaya çalışılmıştır. 20132018 dönemi için hesaplanan korelasyon analizi Tablo 11 'de verilmiştir.

Tablo 11: 2013-2018 Dönemi İçin Hesaplan Finansal Oranlar Arasındaki Korelasyon Sonuçları

\begin{tabular}{ccccccc}
\hline \multirow{2}{*}{ SDH } & r & 0,142 & $-0,310$ & $-0,122$ & 0,082 & 0,144 \\
\cline { 2 - 7 } & $\mathbf{p}$ & $\mathbf{0 , 0 0 0}$ & $\mathbf{0 , 0 0 0}$ & $\mathbf{0 , 0 0 0}$ & $\mathbf{0 , 0 1 8}$ & $\mathbf{0 , 0 0 0}$ \\
\hline \multirow{2}{*}{ SAO } & $\mathbf{r}$ & 0,026 & 0,046 & 0,041 & $-0,043$ & 0,042 \\
\cline { 2 - 7 } SNÇS & $\mathbf{p}$ & 0,452 & 0,183 & 0,232 & 0,213 & 0,227 \\
\cline { 2 - 7 } & $\mathbf{P}$ & 0,113 & 0,040 & 0,101 & $-0,122$ & 0,128 \\
\hline SDV & $\mathbf{p}$ & 0,001 & 0,245 & $\mathbf{0 , 0 0 3}$ & $\mathbf{0 , 0 0 0}$ & $\mathbf{0 , 0 0 0}$ \\
\cline { 2 - 7 } & $\mathbf{p}$ & $-0,142$ & 0,000 & $-0,053$ & $-0,126$ & $-0,133$ \\
\hline \multirow{2}{*}{ SBHO } & $\mathbf{0 , 0 0 0}$ & 0,997 & 0,126 & $\mathbf{0 , 0 0 0}$ & $\mathbf{0 , 0 0 0}$ \\
\cline { 2 - 7 } & $\mathbf{p}$ & 0,122 & 0,132 & 0,186 & 0,116 & 0,124 \\
\hline
\end{tabular}

Korelasyon analizi sonuçları incelendiğinde;

Stok devir hızı ile brüt kar oranı arasında negatif yönlü (p=0,012) anlamlı çok zayıf ilişki olduğu tespit edilirken, diğer karlılık oranları arasında $(\mathbf{p = 0 , 0 0 0})$ anlamlı pozitif yönlü zayıf bir ilişkini olduğu tespit edilmiştir.

$>$ Stok aktif oranı ile karlılık oranları arasında anlamlı bir ilişki olmadığı tespit edildi.

$>$ Stokların net çalışma sermayesine oranı esas faaliyet ( $\mathbf{p}$ $=\mathbf{0 , 0 0 3})$ ve öz $\operatorname{kaynak}(\mathbf{p}=\mathbf{0 , 0 0 0}) \operatorname{karl} 1 \mathrm{l} \mathrm{k}$ oranları arasında anlamlı çok zayıf pozitif yönlü bir ilişki olduğu belirlenirken diğer karlılık oranları arasında anlamlı bir ilişki olmadığı belirlendi.

$>$ Stok dönen varlık oranı ile aktif karlılık oranı $(\mathbf{p}=\mathbf{0 , 0 0 0})$; brüt çalışma sermayesi oranı $(\mathbf{p = 0 , 0 0 0})$; ve öz kaynak karlılık oraları $(\mathbf{p = 0 , 0 0 0 )}$; arasında negatif yönlü anlamlı zayıf ilişki olduğu tespit edilirken; diğer oranlar arasında anlamlı bir ilişkili olmadığı tespit edilmiştir.

$>$ Stok büyüme hızı oranının tüm karlılık oranları ile arasında (p=0,000)anlamlı çok zayıf ilişki olduğu tespit edilmiştir.

\section{Sonuç}

Araştırmadan elde edilen sonuçları, uygulanan analiz teknikleri doğrultusunda iki başlık altında özetlemek mümkündür. $\mathrm{Bu}$ başlıklardan ilki regresyon analizi sonuçları diğeri ise ilgileşim analizi sonuçlarıdır. Regresyon analizi sonucunda regresyon modelinde yer alan stok yönetimiyle ilgili oranlar Tablo 12'de özetlemiştir.

Tablo 12: Regresyon Modelinde Yer Alan Stok Yönetim Oranları

\begin{tabular}{ccccc}
\hline Yıllar & $\begin{array}{c}\text { Aktif } \\
\text { Karlılı } \\
\text { Oranı }\end{array}$ & $\begin{array}{c}\text { Brüt } \\
\text { Karlılık } \\
\text { Oran }\end{array}$ & $\begin{array}{c}\text { Esas } \\
\text { Faaliyet } \\
\text { Karlılık } \\
\text { Oranı }\end{array}$ & $\begin{array}{c}\text { Brüt Çalışma } \\
\text { Sermayesi } \\
\text { Karlılık Oranı }\end{array}$ \\
\hline $\mathbf{2 0 1 3}$ & + SAO & + SAO & + SAO & + SAO \\
\hline
\end{tabular}

\begin{tabular}{|c|c|c|c|c|}
\hline & - SDV & - SDV & - SDV & - SDV \\
\hline & $-\mathrm{SBH}$ & & & \\
\hline \multirow{2}{*}{2014} & $+\mathrm{SAO}$ & & & \\
\hline & - SDV & & & \\
\hline \multirow{2}{*}{2015} & $+\mathrm{SAO}$ & & & \\
\hline & - SDV & & & \\
\hline \multirow{3}{*}{2016} & & $+\mathrm{SAO}$ & -SDV & \\
\hline & & - SDV & $-\mathrm{SBH}$ & \\
\hline & & $+\mathrm{SBH}$ & & \\
\hline \multirow{2}{*}{2017} & & $+\mathrm{SAO}$ & & \\
\hline & & $+\mathrm{SDV}$ & & \\
\hline \multirow{3}{*}{2018} & -SDV & $+\mathrm{SAO}$ & -SDV & \\
\hline & $+\mathrm{SBH}$ & - SDH & $+\mathrm{SBH}$ & \\
\hline & & $+\mathrm{SDV}$ & & \\
\hline
\end{tabular}

Tablo incelendiğinde oluşturulan modelde stok yönetim oranlarının çoğunlukla aktif karlılık oranı, brüt karlılık oranı ve esas faaliyet karlılık oranlarının yer aldığ görülmektedir. Bu oranlardan stok aktif oranının yer aldığı modellerde daima bağımlı değişkeni artırıcı etki göstermiştir. $\mathrm{Bu}$ durum sonucunda işletmelerin stok aktif oranlarını kontrol ettiklerinde ve stok aktif oranını yükselttiklerinde karlılıklarının olumlu yönde etkileneceği söylenebilir. Dikkat çekici bir diğer oran ise stok dönen varlık oranı olmuştur. Bu oran 2017 ve 2018 yılları hariç yer aldığı modellerde karlılığı düşürücü etki gösterirken son iki yılda yer aldığı brüt karlılık oranında olumlu etkisinin olduğu tespit edilmiştir. Modelde aktif karlılık, brüt karlılık ve esas faaliyet karlılık modellerinin bazılarında yer alan stok büyüme hızının ise karlılığa olumlu etkisi olduğu tespit edilmiştir. Stok yönetim oranlarındaki bir birim değişiklik karlılık modelinde olumlu etkisi olduğunda kendi katsayısı kadar karlılığa artırıcı etki yaparken; modele olumsuz etkisi olduğunda ise kendi katsayısı kadar da karlılı̆̆ etkisi olduğu söylenebilir.

2013-2018 dönemi bir bütün olarak dĕgerlendirilip finansal oranlar arasında yapılan korelasyon analizi sonucunda aşağıdaki bulgular tespit edilmiştir.

> Stok devir hızı tüm karlılık oranlarıyla ilişkili olup aktif karlılık oranı, brüt çalıma sermayesi karlılık oranı ve öz kaynak karlılık oranı arasında pozitif yönde anlamlı bir ilişki söz konusu iken; brüt karlılık ve esas faaliyet karlılık oranlarına negatif yönde etkilediği tespit edilmiştir. $\mathrm{Bu}$ sonuç dikkate alındığında stok devir hızının yüksek tutulması aktif karlılık, brüt çalışma sermayesi karlılığı ve öz kaynak karlılığını olumlu yönde (artırıcı) etkilediği söylenebilir.

$>$ Stok devir hızı yüksek olan işletmelerin aktif karlılığının da yüksek olması ise, işletmelerde stokların ağırlığının az olmasıyla açıklanabilir. Stoklar varlıklar içinde etkin bir şekilde yönetilmekte ve bu durum da karlılığa olumlu olarak yansımaktadır. İmalat sektöründeki işletmelerimiz satış hacimlerinin artmasına bağlı olarak maliyet artışlarıyla karşılaşmakta; fakat aşırı stok bulundurmayıp talebe göre stoklarını ayarladıklarından stok bulundurma maliyetlerinin azalması karlılıklarında artışlara yol açmaktadır. Fakat brüt karlılık ve esas faaliyet karlılık oranlarını negatif yönde etkilemesi işletmelerin stok bulundurma maliyeti ve finansman kaynaklarını daha kısa süre ile stoklara bağlamış olacağından daha az çalışma sermayesi ihtiyac1 duyacağı anlamına gelir. $\mathrm{Bu}$ durum ise işletmelerin stok bulundurma maliyeti ve finansman 
ihtiyacını azaltacaktır. Dolayısıyla stok devir hızı yüksek olan işletmeler, rekabet avantajı yakalayabilmek için, satışlar üzerinden daha düşük kar oranına razı olabilirler.

$>$ Stok aktif oranı ise karlılık oranları üzerinde pozitif ya da negatif yönlü anlamlı her hangi bir ilişkiye sebep olmadığ 1 tespit edilmiştir.

$>$ Stok net çalışma sermayesi oranı ile esas faaliyet karlılık oranı ve öz kaynak karlılık oranı arasında anlamlı pozitif yönlü bir ilişkinin olduğu tespit edilirken; brüt çalışma sermayesi karlılığıyla arasında negatif yönlü anlamlı bir ilişki olduğu tespit edilmiştir. $\mathrm{Bu}$ sonuçlar dikkate alındığında stok net çalışma sermayesi oranı artırıldığında esas faaliyet karlılık oranı ve öz kaynak karlılık oranı artarken brüt çalışma sermayesi karlılığ 1 azalacaktır.

$>$ Stok dönen varlık oranı ile aktif karlılık oranı, brüt çalışma sermayesi karlılığı ve öz kaynak karlılığı arasında negatif yönlü anlamlı bir ilişkinin olduğu tespit edilmiştir. $\mathrm{Bu}$ sonuç dikkate alındığında stok dönen varlık oranı arttığında işletmenin aktif karlılığı, brüt çalıma sermayesi karlılığının ve öz kaynak karlılığının olumsuz etkileneceği söylenebilir.

$>$ Stok büyüme hızı oranı ile tüm karlılık oranları arasında anlamlı pozitif yönlü ilişkinin olduğu tespit edilmiştir. $\mathrm{Bu}$ sonuç dikkate alındığında stok büyüme hızı oranı arttığında tüm karlılık oranlarının olumlu etkileneceği söylenebilir. $\mathrm{Bu}$ durum şöyle açıklanabilir; stokların belli bir büyüme hızına sahip olması, işletmede satışa ve dolayısıyla kara dönüşebilecek varlıkların artmasına sebep olacaktır. $\mathrm{Bu}$ durum karlılığ etkileyecektir.

\section{Kaynakça}

Agha H. (2014). Impact of Working Capital Management On Profitability. European Scientific Journal, 10(1), 374-381.

Akgüç, Ö. (1998), Finansal Yönetim, Avcıol Basım Yayı, 7.Bask1, İstanbul.

Akgül, A.,\& Cevik O. (2003). Istatistiksel Analiz Teknikleri. Ankara: Emek Ofset.

Albayrak, A. S., \& Akbulut, R. (2008). Kârlılığ́1 etkileyen faktörler: İMKB sanayi ve hizmet sektörlerinde işlem gören işletmeler üzerine bir inceleme. ZKÜ Sosyal Bilimler Dergisi, 4(7), 55-83.

Altunışık, R., Coşkun,R., Yıldlrım,E.,\& Bayraktaroglu,S. (2001). Sosyal Bilimlerde Araştırma Yöntemleri. Adapazarı: Sakarya Kitabevi.

Aygün, M. (2012). Firma Performansı Üzerinde Çalışma Sermayesinin Etkisi: Türk İmalat Sektörü Üzerine Bir Uygulama. Ege Akademik Bakış, 12(2), 215-223.

Ayub, M. Y. (2015). Impact of Working Capital Management on Profitability of Textile Sector of Pakistan. International Journal of Information, Business and Management, 7(1), 174-192.

Coşkun E.,\& Kök D. (2011). Çalışma Sermayesi Politikalarının Karlılık Üzerine Etkisi: Dinamik Panel Uygulaması. Ege Akademik Bakış, 11, 75-85.
Doğan, M. (1982).İşletme Ekonomisi ve Yönetimi. İzmir: Yasar Eğitim ve Kültür Vakfi.

Gamgam, R., \& Altunkaynak, B. (2017).SPSS Uygulamal Regresyon Analizi. Ankara: Seçkin Yayıncılık.

Gökşen, Y. (2003). Geleneksel Üretimden Esnek Üretime: Karşılaştırmalı Bir İnceleme. Dokuz Eylül Üniversitesi Sosyal Bilimler Enstitüsü Dergisi, 5(4), 32-48.

Güneş, F. (2012).Elektronik Ticaret Uygulamasının Stok Yönetimi Boyutunda Analizi ve Bir Uygulama. Yüksek Lisans Tezi. Konya: Selçuk Üniversitesi.

Gürçay, G. (2012).Yöneticiler Için Temel Stok Kontrolü. İstanbul: Çatı Kitapları.

Kara, Ö. (2014). Işletmelerde Stok Yönetimi. Yüksek Lisans Tezi. İstanbul: Okan Üniversitesi

Karagöz, Y. (2016).SPSS 23 ve AMOS 23 Uygulamal Ístatistiksel Analizler. Ankara: Nobel Akademik Yayıncilık.

Kindik, N.,\& Arslan, A. (2017). Kârlılık Sürdürülebilirliği ve Kârlılığı Etkileyen Faktörlerin Analizi: Bir Kooperatif İşletmesi Olan Konya Şeker Fabrikası. Üçüncü Sektör Sosyal Ekonomi Dergisi, 52, 608-626.

Kiracı, M. (2009). Stok Yönetimi ve Karlılık İlişkisinin Finansal Oranlar Aracılığıyla İncelenmesi: İMKB İmalat Sektöründe Bir Araştırma. ODTÜ Geliştirme Dergisi, 36( 1), 161-195.

Kutluata, M. (1954).IŞsletmelerde Prodüktivite - Rantabilite İlişkileri.İstanbul: Reklam Yayınları.

Küçük, O. (2011). Stok Yönetimi. Ankara: Seçkin Yayınc1lik

Külter, B., \& Demirgüneş, K. (2007). Perakendeci Firmalarda Kârlılığı Etkileyen Değişkenler Hisse Senetleri İMKB'de İşlem Gören Perakendeci Firmalar Üzerinde Ampirik Bir Çalışma. Ç.Ü. Sosyal Bilimler Enstitüsü Dergisi, 16(1), 445-460.

Makori, D. M., \& Jagongo A. (2013).Working Capital Management and Firm Profitability: Empiricial Evidence from Manufacturing and Construction Firms Listed on Nairobi Securities Exchange, Kenya. International Journal of Accounting and Taxation, 1(1), 1-14.

Richard, H., \& Parrısh, M.S. (1986). The Relationships Between Profitability, Inventory Efficiency, and Gross Margin Return on Investment in Alabama Community Pharmacies.Journal of Pharmaceutical Marketing \& Management, 1(1), 203-225.

Sevilengül, O. (2005). Genel Muhasebe. Ankara: Gazi Kitabevi.

Seyidoğlu, H. (1992).Ekonomik Terimler: Ansiklopedik Sözlük.Ankara: Güzem Yayıncılık.

Sharma, A. K., \& Kumar S. (2011). Effect of Working Capital Management on Firm Profitability: Empiricial Evidence from India. Global Business Review.12(1),159-173.

Tekin, M. (2006).Üretim Yönetimi.Konya: Günay Ofset. 
Tersine R. J. (1994).Principles of Inventory and Materials Management. New Jersey: Prentice Hall.

Top A.(2006). Üretim Yönetimi. Ankara: Nobel Yayın Dağıtım.

Vahid, T. K., Elham, G., Mohsen, A. K. \& Mohammadreza, E. (2012). Working Capital Management and Corporate Performance: Evidence from Iranian
Companies. Procedia Social and Behavioral Sciences, 62, 1313-1318.

Yazıcıoğlu, Y., \& Erdoğan, S. (2004).SPSS Uygulamalı, Bilimsel Araştırma Yöntemleri, Ankara: Detay Yayıncilik. 